François Gipouloux, The Asian Mediterranean: Port Cities and Trading Networks in China, Japan and Southeast Asia, $13^{\text {th }}-21^{\text {st }}$ Century, translated by Jonathan Hall and Dianna Martin, Cheltenham and Northampton, MA, Edward Elgar Publishing, 2011, 407 pp.

\title{
Angela Schottenhammer
}

\section{(2) OpenEdition}

\section{Journals}

Electronic version

URL: http://journals.openedition.org/chinaperspectives/6492

DOI: 10.4000/chinaperspectives.6492

ISSN: 1996-4617

\section{Publisher}

Centre d'étude français sur la Chine contemporaine

Printed version

Date of publication: 1 June 2014

Number of pages: 78-79

ISSN: 2070-3449

\section{Electronic reference}

Angela Schottenhammer, "François Gipouloux, The Asian Mediterranean: Port Cities and Trading Networks in China, Japan and Southeast Asia, $13^{\text {th }}-27^{\text {st }}$ Century, », China Perspectives [Online], 2014/2 I 2014, Online since 01 January 2017, connection on 23 September 2020. URL : http:// journals.openedition.org/chinaperspectives/6492; DOI : https://doi.org/10.4000/chinaperspectives. 6492

This text was automatically generated on 23 September 2020

(c) All rights reserved 


\section{François Gipouloux, The Asian} Mediterranean: Port Cities and Trading Networks in China, Japan and Southeast Asia, $13^{\text {th }}-21^{\text {st }}$ Century,

translated by Jonathan Hall and Dianna Martin, Cheltenham and Northampton, MA, Edward Elgar Publishing, 2011, 407 pp.

Angela Schottenhammer

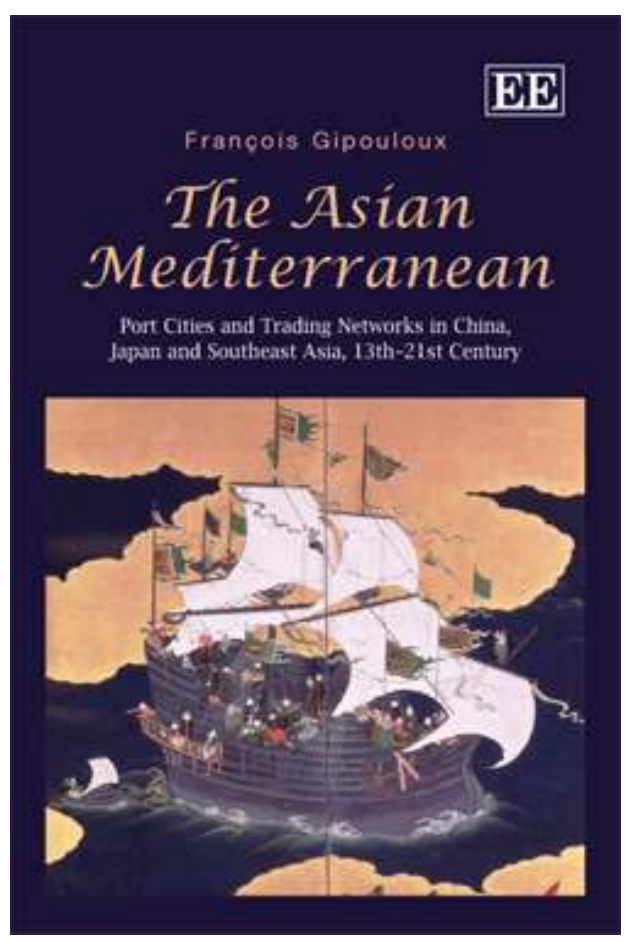

Méditerranée asiatique. Villes portuaires et réseaux marchands en Chine, au Japon et en Asie du Sud-Est, 
$\mathrm{XVI}$-XXI siècle (Paris, CNRS Éditions), providing scholars for the first time with a general Braudelian synthesis that compared the European and the Asian "Mediterraneans." $\mathrm{He}$ distinguished three different Mediterranean spaces: the European Méditerranées of the repubbliche marinare, the Hanseatic League in the Baltic Seas, and the Asian Mediterranean comprising the Sea of Japan, the Yellow Sea, the South China Sea, the Sulu Sea, and the Sea of the Célèbes. The present volume is basically an English translation of the French version published in 2009. I say basically because the book constitutes a slightly updated and revised version of the French original. I previously criticised Gipouloux's analysis of historical periods, saying that it "frequently remains general and seems to have drawn basically on older publications. In this context, it is astonishing that there is almost no mention of the more recent publications concerning aspects of an Asian Mediterranean (including those of my former research team at Munich University), as well as more specific topics of historical phases that are discussed, even though they were published before 2008. Consequently, the historical part of this book does not really represent the actual state of scholarship and knowledge."1 In his English edition, Gipouloux has reviewed recent literature and has at least updated the bibliography as well as some references. The 12 maps that were originally published as a coloured set in the middle of the book are definitely better in the French version, having been replaced with simple black-and-white maps in the English edition.

The volume is divided into five main parts with a total of 20 chapters. Part 1 (The Models of Expansion without Borders: The European Mediterraneans) introduces the general geographical, political, and economic framework and then discusses the two European "models of expansion without borders," the European Mediterranean republics (repubbliche marinare), and the Hanseatic League. With Part 2 (Early Outlines of an Asian Mediterranean: The Predominance of Tributary Trade), Gipouloux moves to the "Asian Mediterranean," emphasising government monopolies - in contrast to the free private trade of the European Mediterraneans - and discusses the role of tributary trade and smuggling. A special section is dedicated to Japan and its reluctance to simply follow the Ming Chinese "tribute order." Japan initiated her own system and "selectively closed" herself off from the outer world - it is refreshing to read that Gipouloux is aware of the fact that this closure was not a complete and total one. The last section of this part summarises the characteristics of the Asian "maritime system," which, according to Gipouloux, appears as an interwoven, complex network of Chinese, Japanese, and also Western activities based on a limited number of large emporia. I would like to highlight here that he correctly views Ming China's maritime trade proscription as the reason for the rise of piracy and disorder and not vice versa, as is often claimed ("The policy of banning maritime trade, the purpose of which was to prevent exchange, had unexpected consequences: the blockade of all commercial activity along the coast of China let to a state of disorder caused by pirates," p. 108).

3 Part 3 (The Overlapping of Western and Asian Trading Networks) brings the Europeans onto the arena. Gipouloux speaks of "overlapping networks," thus explicitly criticising the idea that while the Europeans advanced dynamically or even aggressively, Asian countries passively endured European dominance. The section briefly discusses the changes the advent of the Europeans brought about for Asia's maritime system, eventually leading to the forced opening of ports. He particularly analyses Singapore, Hong Kong, and Shanghai as "outcomes" of a prolonged interaction between Chinese and foreign traders. The focus definitely lies on developments in the eighteenth and nineteenth centuries; early European expansion is only briefly discussed. 
4 Part 4 (The Arena of Re-Globalization: The Second Birth of the Asian Mediterranean) treats the rapid economic development of modern coastal cities, "born" this time of the reform programme of the Chinese Communist Party (CCP). Gipouloux focuses especially on the competition between Hong Kong and Shanghai as commercial and financial centres (in contrast to the industrial manufacturing sector). The Mao era is only very briefly referred to, the emphasis lying on developments after 1984. Again Gipouloux links tradition with modernity: in his eyes, the reform policies of the Deng Xiaoping era "reactivated the mechanisms linking market and urbanisation, which had appeared under the Sung from the $10^{\text {th }}$ to the $13^{\text {th }}$ centuries" (p. 181), while during the early Communist era the port cities "experienced a long period of hibernation" (p. 173). In the Braudelian sense, Gipouloux describes the emergence of an East Asian economic corridor (see map 17.1, p. 262). Geography, economy, and international relations constitute a transnational, maritime area, the modern "Asian Mediterranean," with its respective integration of the hinterlands into the network system.

5 Part 5 (The Asian Mediterranean and the Challenges to State Sovereignty) examines the challenges this East Asian economic corridor creates for state sovereignty. "External dynamic forces" cause "China's economic space to break up and re-form" (p. 3), a development that eventually causes China to increasingly turn towards maritime Asia and to open up. Despite certain protectionist measures, which Gipouloux considers side effects of its economic transformation, China is becoming more open, more maritime, more cosmopolitan - in other words, a "flexible empire" linking up with the Zheng He expeditions of the early fifteenth century (p. 4). China is now challenging the other economic powers adjacent to the Asian Mediterranean.

6 The Asian Mediterranean (or its French original) is definitely the first work to not only link the past with the present, but also to provide a more general Braudelian synthesis of the Asian maritime world, along with comparisons with two historical examples of European Mediterraneans and pulling together a great deal of relevant information. This alone undoubtedly deserves much credit. Nobody has dared or made the effort to write such a synthesis before.

7 The strength of Gipouloux's argumentation, however, lies not in historical China but in the present, especially in the decades after the gradual opening of China with the reforms of Deng Xiaoping. I would therefore recommend this book to anyone who is interested in a general Braudelian synthesis of the Mediterranean in a real global context, to scholars who look for similarities between not only Asia and Europe but also past and present, and to those who want to know more about the economic development of modern Chinese port cities including cities such as Hong Kong or Singapore - and parallels between Chinese and other Asian port cities located in the Asian maritime corridor as portrayed on map 17.1. It is definitely a must for global historians with a focus on Asia. The historian of China will not find much new information, although he/she will be satisfied to read Gipouloux's correct assessment of past developments, such as the causes of the Zheng He expeditions or the Ming maritime trade proscription, which are sometimes obscured in writings on China's history. We learn that although China, or Asia in general, with few exceptions, does not have a tradition of free cities or something comparable to the Hanseatic League in Europe, it has become a "flexible empire" (p. 4) due to its inexorably developing coastal cities (p. 328). 


\section{NOTES}

1. See my book review published in T'oungPao, Vol. 96, No. 4, 2010, pp. 581-585.

\section{AUTHOR}

\section{ANGELA SCHOTTENHAMMER}

is full Professor of non-European and world history (focus China) at the University of Salzburg, Austria, and research director of the Indian Ocean World Centre and adjunct professor at McGill University, Canada (Angela.Schottenhammer@sbg.ac.at). 